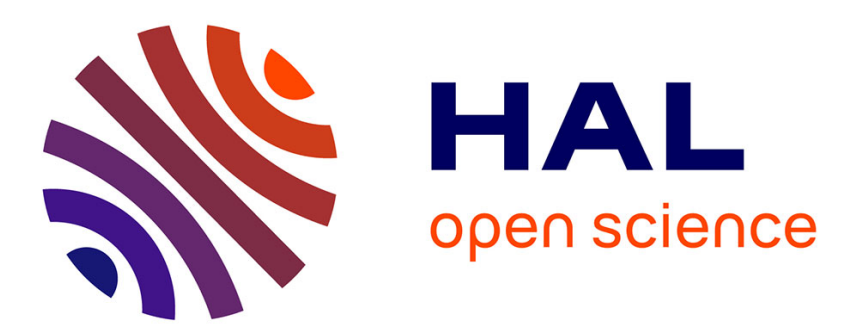

\title{
The spread of var. in the Mediterranean Sea: an example of how biological invasions can influence beta diversity
}

Luigi Piazzi, David Balata

\section{- To cite this version:}

Luigi Piazzi, David Balata. The spread of var. in the Mediterranean Sea: an example of how biological invasions can influence beta diversity. Marine Environmental Research, 2007, 65 (1), pp.50. 10.1016/j.marenvres.2007.07.002 . hal-00501922

\section{HAL Id: hal-00501922 \\ https://hal.science/hal-00501922}

Submitted on 13 Jul 2010

HAL is a multi-disciplinary open access archive for the deposit and dissemination of scientific research documents, whether they are published or not. The documents may come from teaching and research institutions in France or abroad, or from public or private research centers.
L'archive ouverte pluridisciplinaire HAL, est destinée au dépôt et à la diffusion de documents scientifiques de niveau recherche, publiés ou non, émanant des établissements d'enseignement et de recherche français ou étrangers, des laboratoires publics ou privés. 


\section{Accepted Manuscript}

The spread of Caulerpa racemosa var. cylindracea in the Mediterranean Sea: an example of how biological invasions can influence beta diversity

Luigi Piazzi, David Balata

PII:

S0141-1136(07)00102-X

DOI:

10.1016/j.marenvres.2007.07.002

Reference:

MERE 3139

To appear in:

Marine Environmental Research

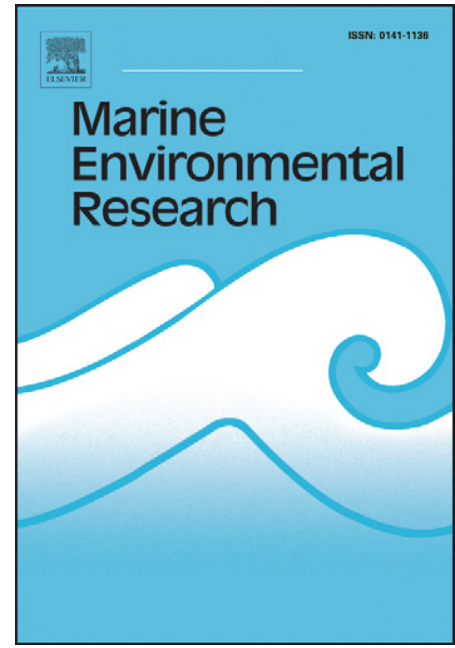

Received Date: $\quad 12$ March 2007

Revised Date: $\quad 27$ July 2007

Accepted Date: $\quad 30$ July 2007

Please cite this article as: Piazzi, L., Balata, D., The spread of Caulerpa racemosa var. cylindracea in the Mediterranean Sea: an example of how biological invasions can influence beta diversity, Marine Environmental Research (2007), doi: 10.1016/j.marenvres.2007.07.002

This is a PDF file of an unedited manuscript that has been accepted for publication. As a service to our customers we are providing this early version of the manuscript. The manuscript will undergo copyediting, typesetting, and review of the resulting proof before it is published in its final form. Please note that during the production process errors may be discovered which could affect the content, and all legal disclaimers that apply to the journal pertain. 
The spread of Caulerpa racemosa var. cylindracea in the Mediterranean Sea: an example of how biological invasions can influence beta diversity

Luigi Piazzi, David Balata*

Dipartimento di Biologia, Università di Pisa

Via A. Volta 6

56126 Pisa, Italy

* Corresponding author

e-mail: dbalata@biologia.unipi.it

Tel: +390502211415

Fax: +39050 2211410 


\title{
ACCEPTED MANUSCRIPT
}

\begin{abstract}
The present study aims to evaluate if invasion of Caulerpa racemosa var. cylindracea can affect both alpha and beta diversity in Mediterranean coastal system. The following hypotheses were tested: i) measures of alpha diversity differ between invaded and non invaded assemblages ii) this pattern is consistent between different habitats, iii) assemblages from habitats which are naturally very different tend to be more similar when invaded compared to non-invaded situations. Results showed that Mediterranean benthic assemblages invaded by $C$. racemosa var. cylindracea were characterized by lower values of alpha diversity than non-invaded assemblages; moreover, differences between deep (25 $\mathrm{m})$ and shallow water $(5 \mathrm{~m})$ assemblages appeared lower in invaded than in non-invaded areas, with a decrease of beta diversity. This homogenisation of habitats was related to a lack of several characteristic species and to a higher abundance of few opportunistic species in invaded areas, particularly turf-forming algae. Moreover, variability in taxa composition was lower in invaded than in non-invaded assemblages in both habitats.
\end{abstract}

KEY WORDS: beta diversity, biological invasion, Caulerpa racemosa var. cylindracea, sublittoral, Mediterranean Sea 


\section{ACCEPTED MANUSCRIPT}

\section{Introduction}

Biological invasions represent an important component of human-induced global changes with serious consequences for ecological, economic and social systems (Vitousek et al., 1996; 1997; Occhipinti-Ambrogi and Savini, 2003). In marine systems, biological invasions are particularly severe with usually profound impacts on structure and functioning of ecological systems, by reducing native species richness and altering ecological processes (Ribera and Boudouresque, 1995; Grosholz, 2002; Larned, 2003; Ruesink et al., 2006).

The influences of biological invasions on biodiversity and on the integrity of natural assemblages are widely investigated in aquatic systems (Cohen and Carlton, 1998; Carlton, 1999; Scheibling and Gagnon, 2006). Invaders are normally highly competitive (Rejmánek and Richardson, 1996) and their interaction with native species can cause the extinction or a strong reduction of the latter, leading to a decrease of ecosystem biodiversity (Walker and Kendrick, 1998; Bax et al., 2003). Most of the studies related to biological invasions have used species richness (the number of species in a community) and/or alpha diversity (includes both the number of species and the relative abundance of individuals) as a surrogate of biodiversity (Viejo, 1997; Piazzi and Cinelli, 2003; Casas et al., 2004, Buschbaum et al., 2006). However, biological invasions can influence other aspects of biodiversity. It has been shown that invaded habitats tend to become similar independently of their native characteristics (McKinney, 2004; McKinney and Lockwood, 1999). Consequently, the invasion process causes a decrease of between-habitats diversity (beta diversity) (Gray, 1997). This aspect of biodiversity is considered key to understanding the functioning of ecosystems and to the conservation and sustainable use of biodiversity (Legendre et al., 2005), but it has not been much a focus enough in relation to biological invasions in marine systems. In the Mediterranean Sea, invasions of the green algae of the genus Caulerpa represent an important threat to the biodiversity of benthic coastal systems (Boudouresque and Verlaque 


\section{ACCEPTED MANUSCRIPT}

2002). In particular, Caulerpa racemosa (Forsskål) C. Agardh var. cylindracea (Sonder)

Verlaque, Huisman et Boudouresque (Verlaque et al., 2003) (C. racemosa from here after)

has rapidly and successfully invaded wide areas of this basin, forming permanent populations

and strongly interfering with native species (Piazzi et al., 2001; 2005b; Ruitton et al., 2005a).

C. racemosa is able to overgrow other macroalgal species, reaching virtually $100 \%$ cover in invaded areas (Piazzi et al., 2001; Balata et al., 2004). This spatial dominance can modify the structure and composition of invaded assemblages and reduce differences between habitats, leading to habitat homogenisation.

The aim of the present study was to evaluate if invasion of $C$. racemosa can affect both alpha and beta diversity. In order to verify these two models, the following hypotheses were tested: i) measures of alpha diversity differ between invaded and non invaded assemblages ii) this pattern is consistent between different habitats, iii) assemblages from habitats which are naturally very different tend to be more similar when invaded compared to non-invaded situations.

\section{Material and methods}

The study was carried out on the rocky coast of Tuscany, in the north-western Mediterranean Sea. In this geographic area Caulerpa racemosa was introduced in 1993 and now the alga colonizes wide zones along the continental and insular coasts from 0 to more than 40 meters in depth (Piazzi et al., 2005b).

We selected two habitats at different depths: $5 \mathrm{~m}$ and $25 \mathrm{~m}$. For each of the two habitats, 4 locations about $1000 \mathrm{~m}^{2}$ wide and with similar exposure to light, currents and wave energies, were chosen a few km apart. For each habitat, 2 locations were invaded by $C$. racemosa for at least two years, while the other 2 were non-invaded. Invaded and non-invaded locations were interspersed. At each location, two sites of about $100 \mathrm{~m}^{2}$ wide and tens of $\mathrm{m}$ apart were chosen on horizontal substrata. In each site, three replicated quadrats of $400 \mathrm{~cm}^{2}$ were 


\section{ACCEPTED MANUSCRIPT}

collected in November 2005 by scraping the substratum with a hammer and a chisel and preserved in formalin. This sampling date was chosen because it is during the peak in biomass production of $C$. racemosa, before the resting winter season (Capiomont et al., 2005; Ruitton et al., 2005b). Algae and sessile invertebrates were identified in the laboratory and their covers determined as percentage of sampling surface covered by vertical projection of each organism.

Alpha diversity was evaluated as the number of taxa per sample and per habitat (point richness and sample richness respectively, sensu Gray 2000) and as evenness (expressed as the Pielou's index). Values of point richness and evenness were analysed by 4-way ANOVAs. with Condition (invaded vs. non-invaded) as fixed factor, Habitat (5 m vs. $25 \mathrm{~m}$ ) as orthogonal and fixed factor, Location (2 levels) as random factor nested in the interaction Condition x Habitat and Site (2 levels) as random factor nested in Location. Homogeneity of variances was checked by Cochran's $C$-test. Student Newman Keuls (SNK) test was used for a posteriori multiple comparison of means (Underwood, 1997).

According to Whittaker (1972), beta diversity can be measured as the variability in species composition among sampling units for a given area at a given spatial scale. Beta diversity was evaluated through a modified version of the Gower's measure of dissimilarity, as described in Anderson et al. (2006). We chose the Gower's measure of dissimilarity because it explicitly weights an order-of-magnitude change in abundance the same as a change in species composition (Anderson et al., 2006). The Gower's measure of dissimilarity was obtained after transforming the data to $\mathrm{x}^{\prime}=\log _{2}(\mathrm{x})+1$ for $\mathrm{x}>0$ and $\mathrm{x}^{\prime}=0$ for $\mathrm{x}=0$, and excluding double zeros. Non parametric multivariate analysis of variance (PERMANOVA) was used to test the hypothesis that assemblages differed between invaded and non-invaded areas and between habitats and to detect eventual interactions between these factors (Anderson, 2001). Factors in the analysis were the same as in univariate analysis. 


\section{ACCEPTED MANUSCRIPT}

Differences in multivariate dispersion between invaded and not-invaded assemblages were tested by PERMDISP analysis on the original Gower's matrix being changes in compositional variability among groups directly interpretable as a change in beta-diversity among groups (Anderson, 2006).

A 2-dimensional nMDS (non metric multidimensional scaling) based on the original Gower's matrix was used for a graphical representation of the data (Clarke and Gorley, 2001).

The program IndVal (Indicator Value) was used to determine which species were responsible for the differences between Conditions in each Habitat (Dufrene and Legendre, 1997).

\section{Results}

A total of 107 taxa were identified, 13 Chlorophyta, 12 Ochrophyta, 72 Rhodophyta, 3 Porifera, 6 Bryozoa, 1 Annelida (Table 1 with, nomenclature authority). The total number of taxa was 62 at $5 \mathrm{~m}$ and 82 at $25 \mathrm{~m}$ in non-invaded areas and 41 at $5 \mathrm{~m}$ and 59 at $25 \mathrm{~m}$ in invaded areas. Similarly, the average number of taxa per sample was significantly higher in non invaded than in invaded assemblages and at $25 \mathrm{~m}$ compared to $5 \mathrm{~m}$ (Fig. 1a). The number of taxa also differed between locations (Table 2). ANOVA detected a significant interaction between Condition and Habitat for evenness (Table 2). SNK test showed that non-invaded assemblages had significantly higher evenness values than invaded assemblages at $5 \mathrm{~m}$ but not at $25 \mathrm{~m}$ (Fig. 1b).

nMDS showed that, when invaded by $C$. racemosa, assemblages at 5 and $25 \mathrm{~m}$ were more similar than when non invaded (Fig. 2), which resulted in a significant interaction between Condition and Habitat (Table 3). The structure of algal assemblages also differed among locations, but samples were more dispersed in non-invaded than in invaded areas in both habitats. PERMDISP showed significantly $(F=14.15, P=0.001)$ lower average distance from centroids in invaded $(19.2 \pm 0.8)$ than in non-invaded areas $(24.1 \pm 0.9)$. 


\section{ACCEPTED MANUSCRIPT}

The IndVal analysis showed that the species that mostly contributed to separate invaded locations from non-invaded ones, were Womersleyella setacea at $25 \mathrm{~m}$, Pterosiphonia pennata at $5 \mathrm{~m}$ and Cladophora prolifera and Halopithis incurva at both depths (Fig. 3). Other taxa that contributed to differences between non-invaded and invaded assemblages included erect algae (Halimeda tuna, Flabellia petiolata, Corallina elongata), encrusting Bryozoans (Schizobrachiella sanguinea and Schizomavella cornuta), encrusting algae (Aglaozonia melanoidea and Encrusting Corallinaceae) and several turf species, in particular the epilitic Chlorophyta Pseudochlorodesmis furcellata (Table 4).

\section{Discussion}

Both alpha and beta diversity were lower in areas invaded by Caulerpa racemosa than in noninvaded areas. The low alpha diversity was related to lower mean number of taxa and evenness per sample. At invaded locations, 19 and 23 taxa were not present at 5 and $25 \mathrm{~m}$ respectively, compared to non-invaded locations. Furthermore, assemblages at 5 and $25 \mathrm{~m}$ habitats were more similar in invaded than non-invaded areas, and variability in taxa composition was lower in invaded than noninvaded areas at both depths.

A reduction of alpha diversity in assemblages invaded by $C$. racemosa had been already reported (Piazzi et al., 2001; Balata et al., 2004) and differences between invaded and noninvaded assemblages described in this study are similar to those described previously. These effects can be related to the rapid stoloniferous growth of the alga (Ruitton et al., 2005b) that can inhibit the growth of other sessile species. Inhibition can also be enhanced through sediment trapping (Piazzi et al., 2005a; Piazzi et al., 2007).

Conversely, there are no information on the influence of this species on beta diversity. Beta diversity may be caused by random variation in community 


\section{ACCEPTED MANUSCRIPT}

composition and/or by gradients of environmental factors (Legendre et al., 2005). The latter case applies to the study system, where shallow Mediterranean assemblages tend to be dominated by photophilous algae, mostly Fucophyceae, with abundant turf and a reduced encrusting layer, while deeper assemblages tend to be dominated by encrusting organisms, mostly red algae belonging to Corallinales and animals with calcareous skeletons (Ballesteros, 2006). The reduction of differences between deep and shallow assemblages in areas invaded by $C$. racemosa was related to the lack of several species unique to the two habitats and to the increased abundance of few opportunistic species. Forty\% of the exclusive taxa of the deep habitat and $45 \%$ of the taxa exclusive of the shallow habitat were not present in invaded locations, while opportunistic species such as Cladophora prolifera, Halopithys incurva and several turf-forming species including Womersleyella setacea and Pterosiphonia pennata, dominated the invaded assemblages at both depths. Many of these opportunistic species are considered tolerant to several kinds of disturbance, such as sediment deposition and burial (Gorostiaga et al., 1998; Airoldi, 1998) which could favour their development in invaded areas. Facilitation of turf-forming species in assemblages invaded by $C$. racemosa has been already described, suggesting a synergism between the invader and turfs (Ceccherelli et al., 2002; Piazzi and Ceccherelli, 2006). We can hypothesize that the development of turf-forming algae 
contributed to reduce differences between invaded assemblages, as algal turfs are considered a major components of biotic homogenisation at global scales (Airoldi, 1998; Gorgula and Connell, 2004; Balata et al., 2007).

Although correlative studies such as this cannot identify a cause-effect relationship, the results suggest that Mediterranean habitats invaded by $C$. racemosa tended to lose their natural patterns of variability, leading to a reduction of beta diversity. The loss of spatial variability in different habitats or regions contributes to what is known as "biotic homogenisation" (McKinney and Lockwood, 1999). Biotic homogenisation is considered one of the most prominent forms of biotic impoverishment worldwide and an important aspect in the ecology of invasions (Smart et al., 2006). A loss of alpha and beta diversity, involving the replacement of ecological specialists by widespread generalists, can cause not only a taxonomical homogenization but also a functional homogenisation, with consequent changes in overall community function and a reduction in ecosystem resilience (Olden et al., 2004). Also, homogenisation can be enhanced if the lost species are not randomly distributed among taxonomic and ecological categories (McKinney and Lockwood, 1999).

In the present study, sessile animals were less abundant in invaded than in non-invaded assemblages and Bryozoans were completely absent. Although this relation must be further explored by experimental studies, it represents an important issue related to $C$. racemosa invasion. In fact, the lack of most sessile animals in invaded assemblages can lead to serious functional alterations of invaded ecosystems. Taxonomic and functional homogenisation can reduce the capability of the communities to react to disturbance, increasing the vulnerability to large-scale events, such as environmental alterations or further biological invasions (Cohen and Carlton, 1998). Low functional diversity can also lead to a temporal synchrony in population dynamics and to a 


\section{ACCEPTED MANUSCRIPT}

lack of complementary use of resources in time, increasing availability of resources to non-native species (Stachowicz et al., 2002).

Although beta diversity has been less considered than species richness in marine ecological studies, it represents a fundamental aspect of the ecosystems and a good ecological indicator. Biological invasions may cause contrasting effects on assemblages that are difficult to understand, as richness can increase or decrease as a consequence of invasions (Sanchez et al., 2005; Buschbaum et al., 2006). Increased species richness, however, could be a consequence of ecosystem modification caused by invaders, that promote the colonization of opportunistic species or species characteristic of other habitats (Crooks, 2002; BrittonSimmons, 2004). Both increased or decreased species richness could result in a higher homogenisation of habitats. Thus, impact evaluations of biological invasions should consider not only the total number of species present in an area, but also the species identity and their ecological function.

\section{Acknowledgements}

We wish to thank M. Incera, I. Bertocci and two anonymous referees for their helpful comments that improved the quality of the manuscript.

\section{References}

Airoldi, L. (1998). Roles of disturbance, sediment stress and substratum retention on spatial dominance in algal turf. Ecology, 79, 27592770.

Anderson, M.J. (2001). A new method for a non-parametric multivariate analysis of variance. Austral Ecology, 26, 32-46. 


\section{ACCEPTED MANUSCRIPT}

Anderson, M.J. (2006). Distance-based test for homogeneity of multivariate dispersions. Biometrics, 62, 245-253.

Anderson, M.J., Ellingsen, K.E., and McArdle, B.H. (2006). Multivariate dispersion as a measure of beta diversity. Ecology Letters, 9, 683693.

Balata, D., Piazzi, L., and Cinelli, F. (2004). A comparison among macroalgal assemblages in areas invaded by Caulerpa taxifolia and C. racemosa on subtidal Mediterranean reefs. PSZNI Marine Ecology, 25, 1-13.

Balata, D., Piazzi, L., and Benedetti-Cecchi, L. (2007). Sediment disturbance and loss of beta diversity on subtidal rocky reefs. Ecology, in press.

Ballesteros, E. (2006). Mediterranean coralligenous assemblages : a synthesis of present knowledge. Oceanography and Marine Biology an Annual Review, 44, 123-195.

Bax, N., Williamson, A., Aguero, M., Gonzales, E., and Geeves, W. (2003). Marine invasive alien species: a threat to global biodiversity. Marine Policy, 27, 313-323.

Boudouresque, C.F., and Verlaque, M. (2002). Biological pollution in the Mediterranean Sea : invasive versus introduced macrophytes. Marine Pollution Bulletin, 44, 32-38. 


\section{ACCEPTED MANUSCRIPT}

Britton-Simmons, K.H. (2004). Direct and indirect effects of the introduced alga Sargassum muticum on benthic, subtidal communities of Washington State, USA. Marine Ecology Progress Series, 277, 61-78.

Buschbaum, C., Chapman, A.S., and Saier, B. (2006). How an introduced seaweed can affect epibiota diversity in different coastal systems. Marine Biology, 148, 743-754.

Capiomont, A., Breugnot E., Den Haan M., and Meinesz A. (2005).

Phenology of a deep water population of Caulerpa racemosa in the northwestern Mediterranean Sea. Botanica Marina, 48, 80-83.

Carlton, J.T. (1999). Scale and ecological consequences of biological invasions in the world's oceans. In O.T. Sandlund, P.J. Schei, A. Viken (Eds.), Invasive species and biodiversity management (pp 195-212). Dordrecht: Kluwer Academic Publisher.

Casas, G., Scrosati, R., and Piriz, M.L. (2004). The invasive kelp Undaria Pinnatifida (Phaeophyceae, Laminariales) reduces native seaweed diversity in Nuevo Gulf (Patagonia, Argentina). Biological Invasions, $6,411-416$.

Ceccherelli, G., Piazzi, L., and Balata, D. (2002). Spread of introduced Caulerpa species in macroalgal habitats. Journal of Experimental Marine Biology and Ecology, 280, 1-11.

Clarke, K.R., and Gorley, R.N. (2001). PRIMER v5: User manual/tutorial. PRIMER-E, Plymouth, UK. 


\section{ACCEPTED MANUSCRIPT}

Cohen, A.N., and Carlton, J.T. (1998). Accelerating invasion rate in a highly invaded estuary. Science, 279, 555-558.

Crooks, J.A. (2002). Characterizing ecosystem-level consequences of biological invasions: the role of ecosystem engineers. Oikos, 97, 153-166.

Dufrene, M., and Legendre, P. (1997). Species assemblages and indicator species: the need for a flexible asymmetrical approach. Ecological Monographs, 7, 345-366.

Gorgula, S.K. and Connell, S.D. (2004). Expansive covers of turf-forming algae on humandominated coast: the relative effects of increasing nutrient and sediment loads. Marine Biology, 145, 613-619.

Gorostiaga, J.M., Santolaria, A., Sacilla, A., and Diez, I. (1998). Sublittoral benthic vegetation of the Eastern Basque Coast (N. Spain): structure and environmental factors. Botanica Marina, 41, 455-465.

Gray, J.S. (1997). Marine Biodiversity: patterns, threats and conservation needs. Biodiversity and Conservation, 6, 153-175.

Gray, J.S. (2000). The measurement of marine species diversity, with an application to the benthic fauna of the Norwegian continental shelf. Journal of Experimental Marine Biology and Ecology, 250, 23-49.

Grosholz, E.D. (2002). Ecological and evolutionary consequences of coastal invasions. Trends in Ecology and Evolution, 17, 22-27.

Larned, S.T. (2003). Effects of the invasive non-indigenous seagrass Zostera japonica on nutrient fluxes between the water column and 


\section{ACCEPTED MANUSCRIPT}

benthos in NE Pacific Estuary. Marine Ecology Progress Series, 254, 69-80.

Legendre, P., Borcard, D., and Peres-Neto, P.R. (2005). Analyzing beta diversity: partitioning the spatial variation of community composition data. Ecological Monographs, 75, 435-450.

McKinney, M.L. (2004). Measuring floristic homogeneization by nonnative plants in North America. Global Ecology and Biogeography, 13, 47-53.

McKinney, M.L., and Lockwood, J.L. (1999). Biotic homogenisation: a few winners replacing many losers in the next mass extinction. Trends in Ecology and Evolution, 14, 450-453.

Occhipinti-Ambrogi, A., and Savini, D. (2003). Biological invasion as a component of global change in stressed marine ecosystems. Marine Pollution Bulletin, 46, 542-551.

Olden, J.D., Poff, N.L., Douglas, M.R., Douglas, M.E., and Faush, K.D. (2004), Ecological and evolutionary consequences of biotic homogenisation. Trends in Ecology and Evolution, 19, 18-24.

Piazzi, L., and Ceccherelli, G. (2006). Persistence of biological invasion effects: recovery of macroalgal assemblages after removal of Caulerpa racemosa var. cylindracea. Estuarine Coastal and Shelf Sciences, 68, 455-461. 


\section{ACCEPTED MANUSCRIPT}

Piazzi, L., and Cinelli, F. (2003). Evaluation of benthic macroalgal invasion in a harbour area of the western Mediterranean Sea. European Journal of Phycology, 38, 223-231.

Piazzi, L., Ceccherelli, G., and Cinelli, F. (2001). Threat to macroalgal diversity: effects of the introduced green alga Caulerpa racemosa in the Mediterranean. Marine Ecology Progress Series, 210, 161-165.

Piazzi, L., Balata, D., Ceccherelli, G., and Cinelli, F. (2005a). Interactive effect of sedimentation and Caulerpa racemosa var. cylindracea invasion on macroalgal assemblages in the Mediterranean Sea. Estuarine Coastal and Shelf Sciences, 64, 467-474.

Piazzi, L., Meinesz, A., Verlaque, M., Akçali, B., Antolić, B., Argyrou, M., Balata, D., Ballesteros, E., Calvo, S., Cinelli, F., Cirik, S., Cossu, A., D’Archino, R., Djellouli, S.A., Javel, F., Lanfranco, E., Mifsud, C., Pala, D., Panayotidis, P., Peirano, A., Pergent, G., Petrocelli, A., Ruitton, S., Žuljević, A., and Ceccherelli, G. (2005b). Invasion of Caulerpa racemosa var. cylindracea (Caulerpales, Chlorophyta) in the Mediterranean Sea: an assessment of the early stages of spread. Cryptogamie Algologie, 26, 189-202.

Piazzi, L., Balata, D., Foresi, L., Cristaudo, C., and Cinelli, F. (2007). Sediment as a constituent of Mediterranean benthic communities dominated by Caulerpa racemosa var. cylindracea. Scientia Marina, 71, 129-135.

Rejmánek, M., and Richardson, D.M. (1996). What attributes make some plant species more invasive? Ecology, 77, 1655-1661.

Ribera, M.A., and Boudouresque, C.F. (1995). Introduced marine plants, with special reference to macroalgae: mechanisms and impact. Progress in Phycological Researches, 11: 187-268 


\section{ACCEPTED MANUSCRIPT}

Ruesink, J.L., Feist, B.E., Harvey, C.J., Hong, J.S., Trimble, A.C., and

Wisehart, L.M. (2006). Changes in productivity associated with four introduced species: ecosystem transformation of a pristine estuary. Marine Ecology Progress Series, 311, 203-215.

Ruitton, S., Javel, F., Culioli, J.M., Meinesz, A., Pergent, G., and Verlaque, M. (2005a). First assessment of the Caulerpa racemosa (Caulerpales, Chlorophyta) invasion along the French

Mediterranean coast. Marine Pollution Bulletin, 50, 1061-1068.

Ruitton, S., Verlaque, M., and Boudouresque, C.F. (2005b). Seasonal changes of the introduced Caulerpa racemosa var. cylindracea (Caulerpales, Chlorophyta) at the northwest limit of its Mediterranean range. Aquatic Botany, 82, 55-70.

Sanchez, I., Fernandez, C., and Arrontes, J. (2005). Long-term changes in the structure of intertidal assemblages after invasion by Sargassum muticum (Phaeophyta). Journal of Phycology, 41, 942949.

Scheibling, R.E., and Gagnon, P. (2006). Competitive interactions between the invasive green alga Codium fragile ssp. tomentosoides and native canopy-forming seaweeds in Nova Scotia (Canada). Marine Ecology Progress Series, 325, 1-14.

Smart, S.M., Thompson, K., Marris, R.H., Le Duc, M.G., Maskell, L.C., and Firbank, L.G. (2006). Biotic homogenization and changes in species diversity across human-modified ecosystems. Proceeding of the Royal Society B, 273, 2659-2665. 


\section{ACCEPTED MANUSCRIPT}

Stachowicz, J.J., Fried, H., Osman, R.W., and Whitlatch, R.B. (2002).

Biodiversity, invasion resistance and marine ecosystem function:

reconciling pattern and process. Ecology, 83, 2575-2590.

Underwood, A.J. (1997). Experiments in ecology. Their logical design

and interpretation using analysis of variance (pp 1-504).

Cambridge: Cambridge University Press.

Verlaque, M., Durand, C., Huisman, J.M., Boudouresque, C.F., and le

Parco, Y. (2003). On the identity and origin of the Mediterranean

invasive Caulerpa racemosa (Caulerpales, Chlorophyta). European

Journal of Phycology, 38, 325-329.

Viejo, R.M. (1997). The effects of colonization by Sargassum muticum

on tidepool macroalgal assemblages. Journal Marine Biological

Association UK, 77, 325-340.

Vitousek, P.M., D'Antonio, C.M., Loope, L.L., and Westbrooks, M. (1996).

Biological invasions as global environmental change. American

Scientist, $84,468-478$.

Vitousek, P.M., D'Antonio, C.M., Loope, L.L., Rejmànek, M., and

Westbrooks, M. (1997). Introduced species: a significant component of human-caused global change. NZ Journal of Ecology, 21, 1-16.

Walker, D.I., and Kendrick, G.A. (1998). Threats to macroalgal diversity:

marine habitat destruction and fragmentation, pollution and introduced species. Botanica Marina, 41, 105-112. 
Whittaker, R.H. (1972). Evolution and measurement of species diversity.

Taxon, 21, 213-251. 


\section{Figure captions}

Fig. 1. Number of species (a) and evenness (b) of non-invaded (white)

and invaded (black) assemblages (mean $+\mathrm{SE}, \mathrm{n}=12$ ).

Fig. 2. Non-metric MDS ordination based on Gower's dissimilarity

coefficient applied to species-samples matrix. Circles $=$ assemblages at 5

$\mathrm{m}$ depth, Triangles $=$ assemblages at $25 \mathrm{~m}$ depth, Grey $=$ non-invaded locations, Black = invaded locations.

Fig. 3. Percentage cover (mean $+\mathrm{SE}, \mathrm{n}=12$ ) of species that mostly contribute to separate non-invaded assemblages (white) from invaded ones (black). 
Table 1. List of taxa. N-I = non-invaded assemblages; $\mathrm{I}=$ invaded assemblages. Habitats at water depths of $5 \mathrm{~m}$ and $25 \mathrm{~m}$.

\begin{tabular}{|c|c|c|c|c|}
\hline \multirow[t]{2}{*}{ Taxa } & \multicolumn{2}{|c|}{$-5 \mathrm{~m}$} & \multicolumn{2}{|c|}{$-25 \mathrm{~m}$} \\
\hline & N-I & I & N-I & I \\
\hline \multicolumn{5}{|l|}{ Chlorophyta } \\
\hline Bryopsis cupressina J.V. Lamouroux & + & - & + & - \\
\hline \multicolumn{5}{|l|}{ Caulerpa racemosa (Forsskål) C. Agardh var. cylindracea } \\
\hline (Sonder) Verlaque, Huisman et Boudouresque & - & + & - & + \\
\hline Chaetomorpha linum (O.F. Müller) Kützing & + & + & - & - \\
\hline Cladophora echinus (Biasoletto) Kützing & - & - & + & + \\
\hline Cladophora dalmatica Kützing & + & + & - & - \\
\hline Cladophora prolifera (Roth) Kützing & + & + & + & + \\
\hline Codium bursa (Linnaeus) C. Agardh & - & & + & + \\
\hline Flabellia petiolata (Turra) Nizamuddin & + & + & + & + \\
\hline Halimeda tuna (J. Ellis et Solander) J.V. Lamouroux & & - & + & + \\
\hline Palmophyllum crassum (Naccari) Rabenhorst & - & - & + & - \\
\hline Pseudochlorodesmis furcellata (Zanardini) Børgesen & + & - & + & - \\
\hline Valonia macrophysa Kützing & - & - & + & + \\
\hline Valonia utricularis (Roth) C. Agardh & + & - & - & - \\
\hline \multicolumn{5}{|l|}{ Ochrophyta } \\
\hline Cladostephus spongiosus (Hudson) C. Agardh & + & + & - & - \\
\hline Cystoseira spinosa Sauvageau & - & - & + & - \\
\hline Dictyota dichotoma (Hudson) J.V. Lamouroux & + & + & - & - \\
\hline Dictyota linearis (C. Agardh) Greville & - & - & + & + \\
\hline Halopteris filicina (Grateloup) Kützing & + & + & + & + \\
\hline \multicolumn{5}{|l|}{$\begin{array}{l}\text { "Aglaozonia melanoidea (Schousboe ex Bornet) Sauvageau" } \\
\text { phase sporophyte of Cutleria adspersa (Mertens ex Roth) De }\end{array}$} \\
\hline Notaris & + & - & - & - \\
\hline Nereia filiformis (J. Agardh) Zanardini & - & - & + & + \\
\hline Padina pavonica (Linnaeus) Thivy & + & - & - & - \\
\hline Sphacelaria cirrosa (P.H. Roth) C. Agardh & + & + & + & + \\
\hline Sphacelaria plumula Zanardini & - & - & + & + \\
\hline Stypocaulon scoparium (Linnaeus) Kützing & + & + & - & - \\
\hline Zanardinia typus (Nardo) G. Furnari & - & - & + & + \\
\hline \multicolumn{5}{|l|}{ Rhodophyta } \\
\hline Acrodiscus vidovichii (Meneghini) Zanardini & - & - & + & + \\
\hline Acrosorium venulosum (Zanardini) Kylin & + & + & - & - \\
\hline Acrothamnion preissii (Sonder) Wollaston & + & + & + & + \\
\hline Aglaothamnion tenuissimum (Bonnemaison) Feldmann-Mazoyer & - & - & + & + \\
\hline Aglaothamnion tripinnatum (C. Agardh) Feldmann-Mazoyer & + & + & + & - \\
\hline Amphiroa cryptarthrodia Zanardini & - & - & + & + \\
\hline Anotrichium barbatum (C. Agardh) Nägeli & + & - & - & - \\
\hline Antithamnion cruciatum (C. Agardh) Nägeli & + & + & + & + \\
\hline Antithamnion tenuissimum (Hauck) Schiffner & - & - & + & + \\
\hline Apoglossum ruscifolium (Turner) J. Agardh & - & - & + & + \\
\hline Bornetia secundiflora (J. Agardh) Thuret & + & - & - & - \\
\hline Botryocladia botryoides (Wulfen) Feldmann & - & - & + & + \\
\hline Centroceras clavulatum (C. Agardh) Montagne & + & + & - & - \\
\hline
\end{tabular}


Ceramium bertholdii Funk

Ceramium circinatum (Kützing) J. Agardh

Ceramium diaphanum (Lighfoot) Roth

Ceramium flaccidum (Kützing) Ardissone

Ceramium codii (H. Richards) Feldmann-Mazoyer

Champia parvula (C. Agardh) Harvey

Chondria dasyphylla (Woodward) C. Agardh

Chondria capillaris (Hudson) M.J. Wynne

Contarinia peyssonneliaeformis Zanardini

Contarinia squamariae (Meneghini) Denizot

Corallina elongata J. Ellis et Solander

Corallophila cinnabarina (Grateloup ex Bory de Saint-Vincent)

R.E. Norris

Crouania attenuata (C. Agardh) J. Agardh

Dasya ocellata (Grateloup) Harvey

Dasya rigidula (Kützing) Ardissone

Encrusting Corallinaceae

Erythroglossum sandrianum (Kützing) Kylin

Eupogodon planus (C. Agardh) Kützing

"Falkenbergia rufolanosa (Harvey) F. Schmitz " phase

sporophyte of Asparagopsis armata Harvey

Feldmannophycus rayssiae (Feldmann et Feldmann-

Mazoyer)Augier et Boudouresque

Gelidium bipectinatum G. Furnari

Gelidium spathulatum (Kützing) Bornet

Gloiocladia furcata (C. Agardh) J. Agardh

Haliptilon virgatum (Zanardini) Garbary et H.W. Johansen

Halopithys incurva (Hudson) Batters

Halydyction mirabile Zanardini

Herposiphonia secunda (C. Agardh) Ambronn

Heterosiphonia crispella (C. Agardh) M.J. Wynne

Hypnea musciformis (Wulfen) J.V. Lamouroux

Hypoglossum hypoglossoides (Stackhouse) Collins et Harvey

Jania adhaerens J. V. Lamouroux

Jania rubens (Linnaeus) J.V. Lamouroux

Laurencia obtusa (Hudson) J.V. Lamouroux

Lomentaria chylocladiella Funk

Lomentaria verticillata Funk

Meredithia microphylla (J. Agardh) J. Agardh

Monosporus pedicellatus (J.E. Smith) Solier

Nitophyllum punctatum (Stackhouse) Greville

Osmundea pelagosae (Schiffner) F.W. Nam

Peyssonnelia rubra (Greville) J. Agardh

Peyssonnelia squamaria (S.G. Gmelin) Decaisne

Pleonosporium borreri (J.E. Smith) Nägeli

Plocamium cartilagineum (Linnaeus) P.S. Dixon

Polysiphonia elongata (Hudson) Sprengel

Polysiphonia furcellata (C. Agardh) Harvey

Polysiphonia perforans Cormaci, G. Furnari, Pizzuto et Serio

Polysiphonia subulifera (C. Agardh) Harvey

Polysiphonia tripinnata J. Agardh 


\section{ACCEPTED MANUSCRIPT}

Pterosiphonia pennata (C. Agardh) Sauvageau Ptilothamnion pluma (Dillwyn) Thuret

Rhodophyllis divaricata (Stackhouse) Papenfuss

Rhodymenia sp.

Rodriguezella strafforelloi F. Schmitz

Spermothamnion repens (Dillwyn) Rosenvinge

Sphaerococcus coronopifolius Stackhouse

Spyridia filamentosa (Wulfen) Harvey

Symphyocladia marchantioides (Harvey) Falkenberg

Tricleocarpa fragilis (linnaeus) Huisman et R.A. Towsend

Womersleyella setacea (Hollenberg) R.E. Norris

Wrangelia penicillata (C. Agardh) C. Agardh

$\begin{array}{llll}+ & + & - & - \\ + & - & + & - \\ + & - & + & + \\ + & + & - & - \\ - & - & + & + \\ + & - & + & - \\ + & - & + & - \\ + & + & - & - \\ + & + & - & - \\ - & - & + & + \\ + & + & + & + \\ - & - & + & +\end{array}$

\section{Porifera}

Axinella damicornis (Esper 1794)

Cacospongia scalaris (Schmidt 1862)

Spirastrella cunctatrix (Schmidt1868)

\section{Bryozoa}

Myriapora truncata (Pallas 1766)

Schizobrachiella sanguinea (Norman 1868)

Schizomavella cornuta (Heller 1867)

Scropucellaria reptans (Linnaeus 1767)

Reteporella beaniana (King 1846)

Smittina cervicornis (Pallas 1766)

\section{Annelida}

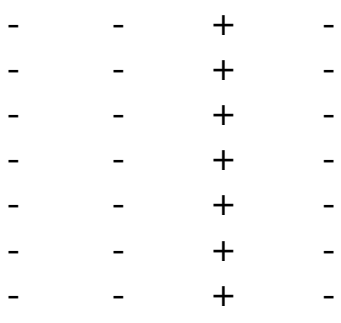


Table 3. Results of PERMANOVA on the structure of assemblages. Significant effects are indicated in bold.

\begin{tabular}{|c|c|c|c|c|c|}
\hline Source & df & MS & ${\text { Pseudo- } F_{\mathrm{P}}}$ & & Denominator terms \\
\hline Condition $=\mathrm{C}$ & 1 & 55608.00 & 35.64 & 0.001 & $\mathrm{~L}(\mathrm{C} \times \mathrm{H})$ \\
\hline Habitat $=\mathrm{H}$ & 1 & 25456.00 & 16.32 & 0.001 & $\mathrm{~L}(\mathrm{C} \times \mathrm{H})$ \\
\hline Location $(\mathrm{C} \times \mathrm{H})=\mathrm{L}(\mathrm{C} \times \mathrm{H})$ & 4 & 1560.30 & 5.34 & 0.001 & $\mathrm{~S}(\mathrm{~L}(\mathrm{C} \times \mathrm{H}))$ \\
\hline Site $(L(C \times H))=S(L(C \times H))$ & 8 & 292.27 & 0.76 & 0.871 & $\mathrm{R}$ \\
\hline $\mathrm{C} \times \mathrm{H}$ & 1 & 6888.80 & 4.42 & 0.005 & $\mathrm{~L}(\mathrm{C} \times \mathrm{H})$ \\
\hline Residual $=\mathrm{R}$ & 32 & 386.01 & & & \\
\hline Total & 47 & & & & \\
\hline
\end{tabular}




\section{ACCEPTED MANUSCRIPT}

Table 4 . Results of the Indicator Species Analysis (IndVal). Habitats at water depths of $5 \mathrm{~m}$ and $25 \mathrm{~m}$.

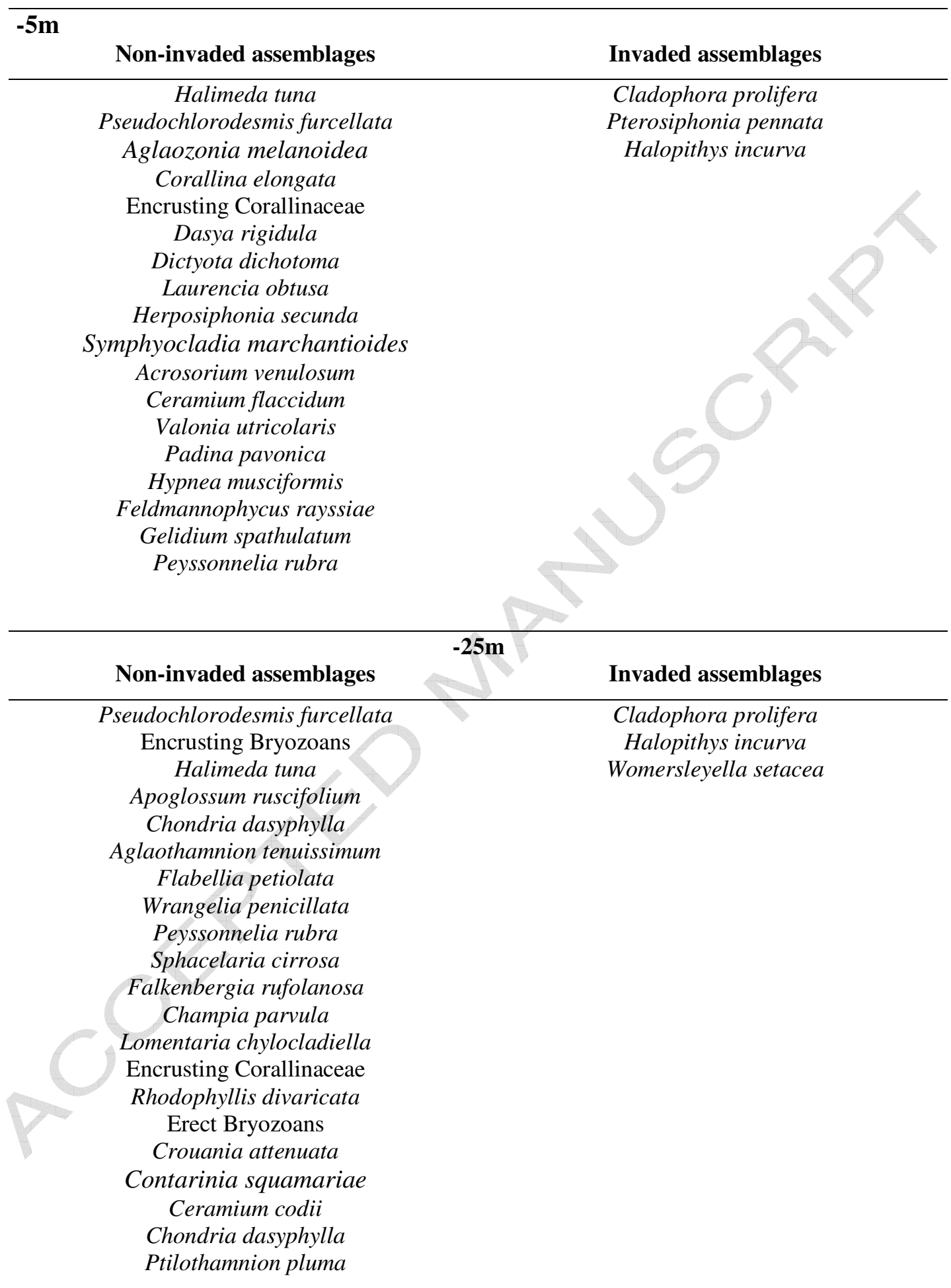


Figure 1
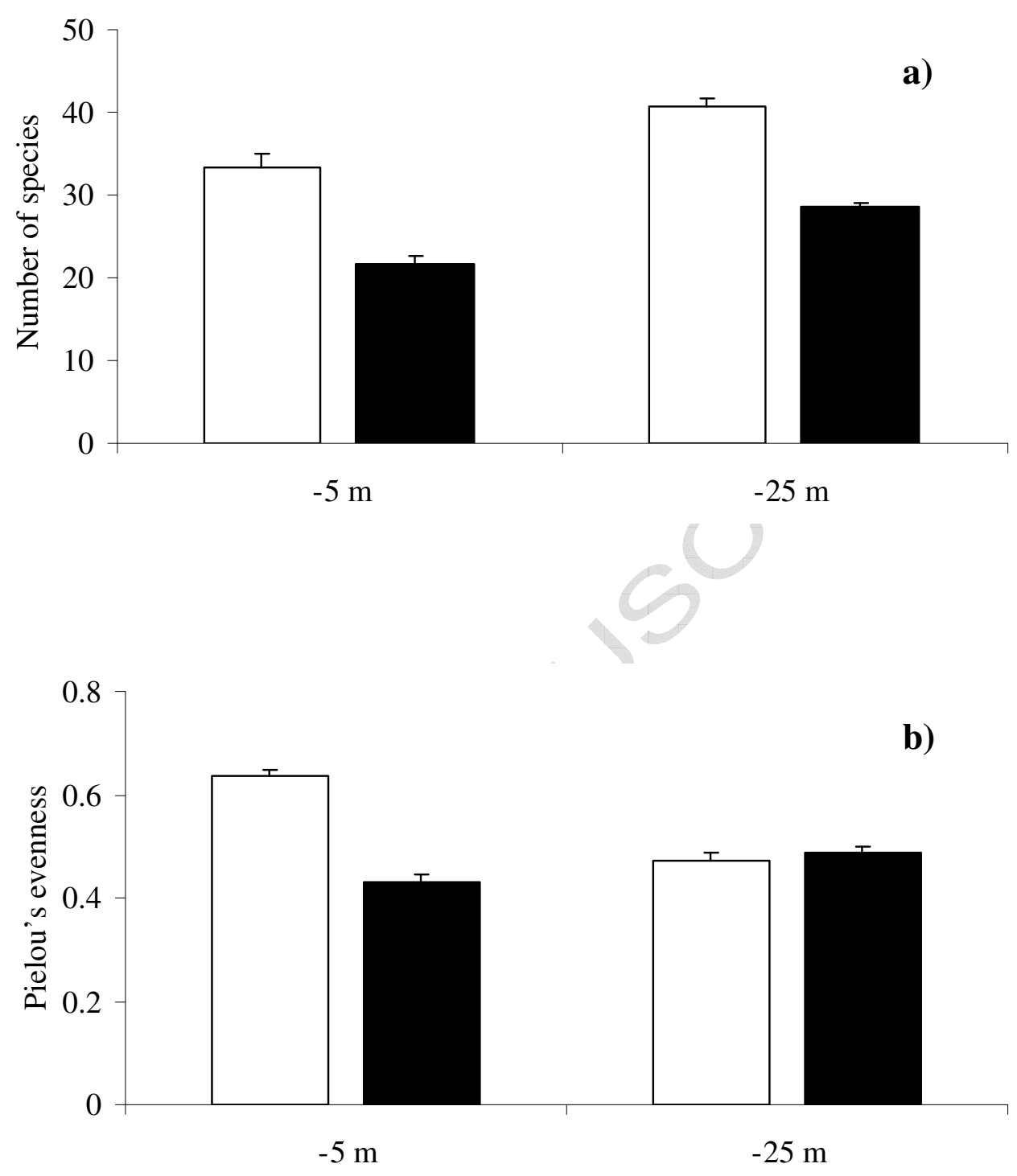
Figure 2

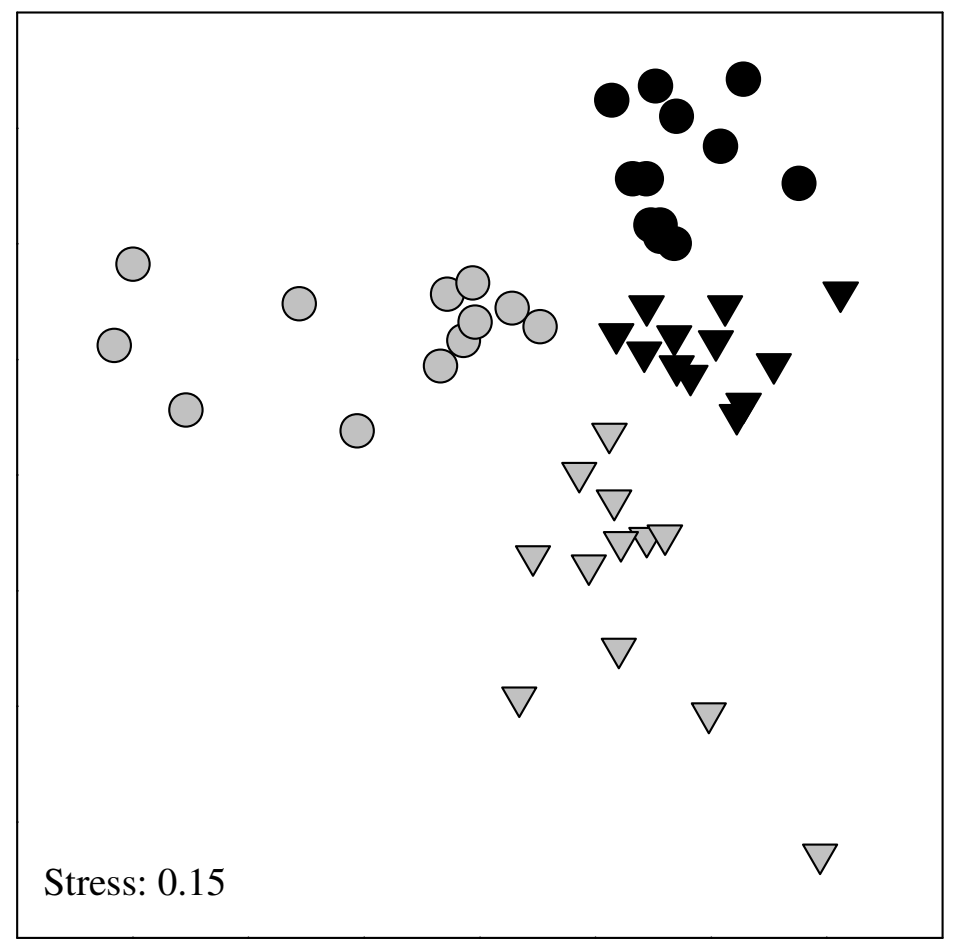


Figure 3

Encrusting Corallinales

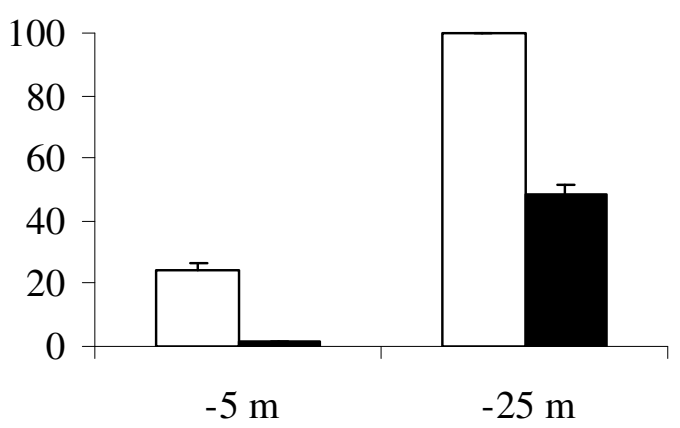

Pseudochlorodesmis furcellata

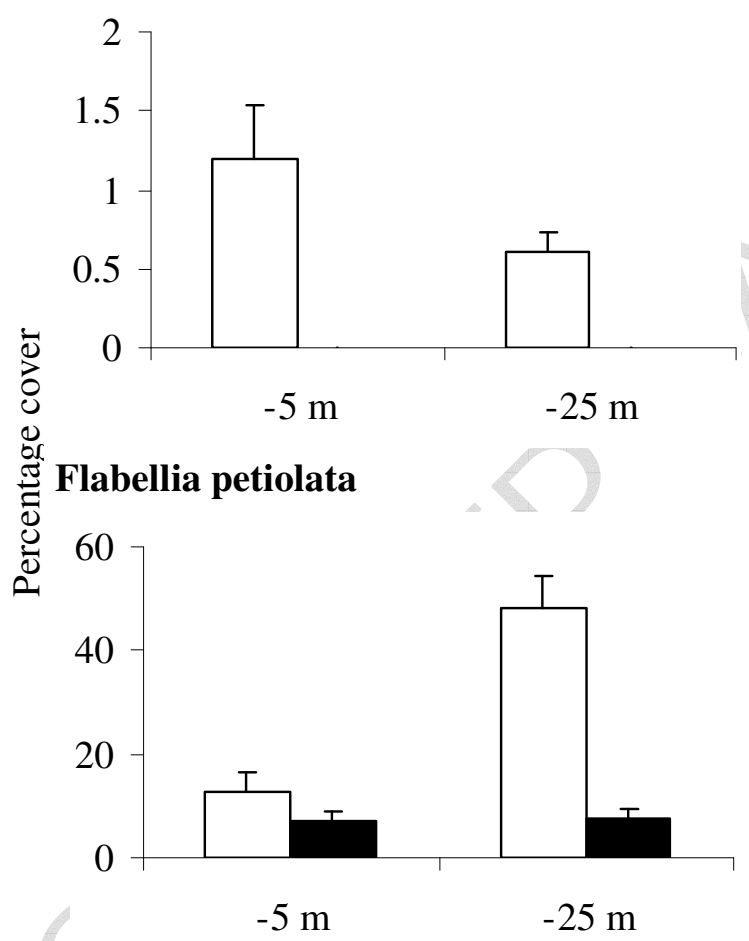

\section{Halimeda tuna}

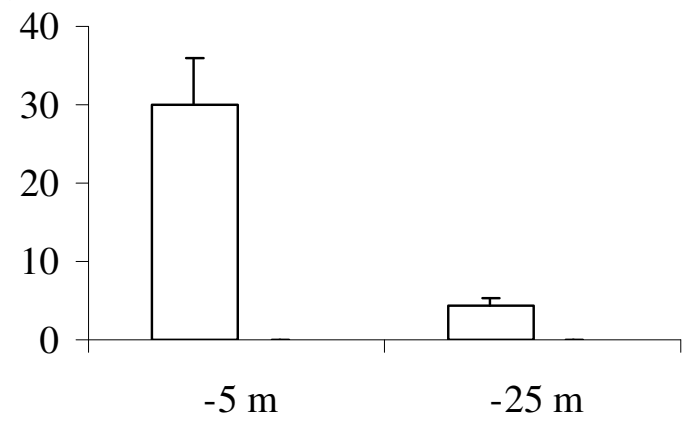

Encrusting Bryozoans

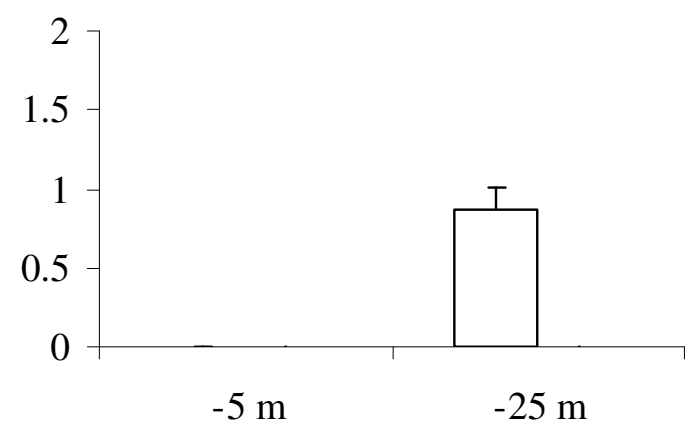

\section{Cladophora prolifera}

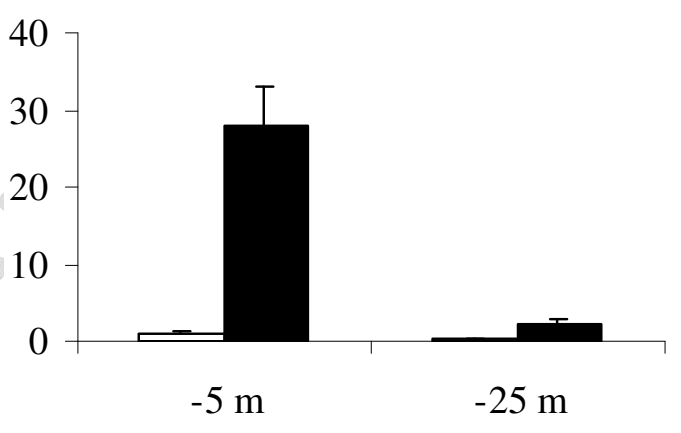

Pterosiphonia pennata

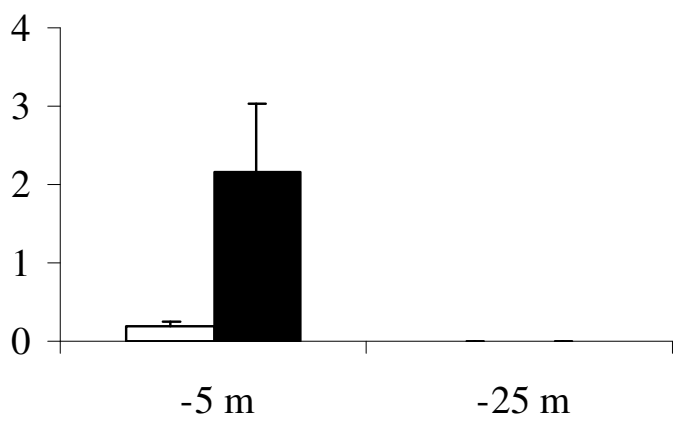

Halopithys incurva

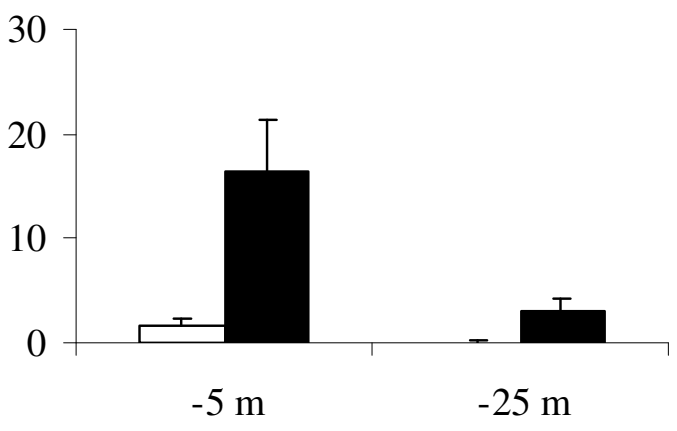

